\title{
Meeting the Needs of Older Students in Higher Education
}

\author{
Gail D. Caruth*
}

Ed.D. Department of Educational Leadership Texas A\&M University-Commerce

\section{Article history}

Received:

11.07.2014

Received in revised form: 21.07.2014

Accepted:

03.08.2014

Key words:

Andragogy, adult learners, adult students, nontraditional students
The number of students 25 years of age and older enrolled in higher education has been escalating over the past 50 years. What is higher education is doing to prepare for this growth? With adults constituting almost half of today's student body, it is important to consider whether the academy is prepared to serve this society of adult learners. The purpose of this paper was to examine the literature on andragogy in higher education to determine if higher education is serving this segment of nontraditional students. Findings show that there has been a substantial increase of adult students enrolled in college and university classes, higher education is not doing the job needed to teach adult learners effectively, adults should be taught andragogically, andragogy is not being used in the higher education classrooms, and colleges and universities need to prepare to teach adult students andragogically. Insufficient empirical research has been conducted on andragogy despite its 40year history of being considered the principal model of adult learning. However, with validated and reliable instruments available to measure the constructs of andragogy, clearer validation of andragogy in higher education is promising. Predictive research can be completed to study the effect of andragogical practices on learning and student satisfaction outcomes. There is the need for further research on andragogy in an attitude of mutuality and reciprocity to develop further the field of adult education. This attitude of mutuality and reciprocity is innovative. 


\section{Introduction}

The number of adults, those 25 years of age and older, enrolled in the academy is escalating (Kasworm, 2012; Marschall \& Davis, 2012). The numbers of adult students attending colleges and universities have increased from 29\% in 1970 to $43 \%$ in 2009 (National Center for Education Statistics [NCES], n.d.a). While almost half of today's overall college student body are adult learners (Altbach, Berdahl, \& Gumport, 2005), many facets of higher education are not designed with adult learners in mind (Tannehill, 2009). American institutions of higher education were originally established with the purpose of educating the privileged youth (Rudolph, 1990; Thelin, 2004). However, colleges and universities over time have begun to educate more adult students (Kasworm, 2012). This need for continuous adult education has created a profitable enterprise (Merriam, Caffarella, \& Baumgartner, 2007) and merits a closer look.

Many could ask what higher education is doing to prepare for this growth. With adults constituting almost half of today's student body, it is important to consider whether the academy is prepared to serve this society of adult learners. The purpose of this paper was to examine the literature on andragogy in higher education to determine if higher education is serving this segment of nontraditional students. Are colleges and universities adequately meeting the needs of the adult learners in and outside of the classroom?

A review of the literature presents a compilation of research, peer-reviewed journals, non-peer reviewed journals, and books on andragogy. The academic databases used were from the online library of Texas A\&M University-Commerce and included, but were not limited to, Academic Search Premier, EBSCO, Education Research Complete, Eric, ProQuest, and Sage Publications. The key descriptive terms used for this research were andragogy, adult learners, adult students, and nontraditional learners.

\section{Significance of the Study}

In 1967, Malcolm Knowles, then professor of education at Boston University and a general consultant in adult education, received the Delbert Clark Award from West Georgia College for his contribution to adult education. This award was considered by many to be the highest national honor in the field of adult education. Furthermore, Knowles was credited for giving "new and special meanings to the term adult education" (p. 350).

The purpose of education is to enable people to develop skills to engage in continuous learning maintained Knowles (1976). Knowles (1968) claimed in his address at the awards banquet that the very survival of civilization requires continuous learning after the formative years. Despite this lack focus on the growth in numbers of adult learners in higher education, Brookfield (2006) suggested the notion that both students and teachers are in positions of encouraging continuous learning.

Knowles (1968) maintained that adult education had undergone immense growth in enrollment. Numerous institutions have recognized adult learning as a major aspect of higher education. Knowles (1968) also acknowledged that adult education is a profitable enterprise. This is demonstrated in the proliferation of for-profit institutions. Knowles claimed that a great deal of money, from a number of sources (government, education, business, and industry), was being invested in adult learning. He stated that not only were more adult learners active in learning than ever before but that adult learning was exploding. 
Knowles stressed that higher education was not fulfilling its educational role of adult education and regrettably others have since verified this position (Harper \& Ross, 2011; Pew, 2007). Knowles also suggested that adult education in higher education had been unsuccessful. He stated that "the biggest obstacle to the achievement of the full potential of adult education has been that it has been tied to and it has been hamstrung by the concepts and the methods of the traditional education of children" (pp. 350-351). According to Pew (2007), administration rarely considers student fulfillment when establishing the curriculum and that the likelihood of getting higher education to take responsibility for the teaching of adult students would be difficult.

Brookfield questioned the lack coverage of adult education in the higher education literature in The Skillful Teacher (2006). This lack of coverage puzzled him because of the growth in the number of adult learners in higher education. He further claimed that textbooks on adult education and learning are seldom recognized in colleges and universities.

Knowles claimed that education was, however, transforming and discovering that adults learned differently than children learn, even though they were still being taught as children were taught. Knowles claimed that the adult curriculum was distinct from the curriculum for youth (Knowles, 1968). His address at the awards banquet was published as an article "Androgogy, Not Pedagogy," which appeared in Adult Leadership in April of 1968. It should be noted that the spelling of androgogy, as it appeared in the article, was later corrected to andragogy because of communications between Knowles and the publisher of MerriamWebster dictionaries (Knowles, Holton, \& Swanson, 2011). This article and his address at the awards banquet at West Georgia College are often referred to as the introduction of the term andragogy to the United States, giving Knowles a lasting link to andragogy (Merriam et al., 2007).

Knowles introduced the term andragogy as the science of teaching adult learners with a focus on the characteristics of adult learners. The term derives from the Greek word andros, which means "man" or "grownups" (Knowles, 1968, p. 351) or agogus meaning "leader of" (Knowles et al., 2011, pp. 59-60), which translates to "the art and science of helping adults learn" (Knowles, 1984, p. 6). Interestingly, Knowles made an important distinction between a pedagog and an andragog. A pedagog, according to Knowles, would want to keep the learner dependent on the teacher, whereas an andragog would encourage the learner to become autonomous in the desire for further inquiry (as cited in Levitt, 1979, p. 53).

Knowles asserted that administration was ultimately responsible for the implementation of andragogy in higher education. He claimed that university administrators violated the principles of andragogy in favor of the movement toward efficiency. In other words, focus was on the highest production for the lowest cost. Sadly this was the focus for administration in spite of the effect it had on students learning. In his opinion, university administration lagged behind management in business and industry who were seeking a balance between the need for human growth and organizational efficiency. Knowles (1976) attributed this gap between higher education and business and industry to higher education's overemphasis on organizational efficiency that unfortunately leads to interference with quality education for students and the society it serves. If higher education is in the business of teaching adult learners, as Pew (2007) maintains, "then the model must be that of Andragogy" (p. 18).

Knowles (1976) claimed that andragogy required a transformation in the student-teacher relationship. The role of the teacher should be analogous to that of a facilitator, something to 
which few teachers have been exposed (Brookfield, 2006; Knowles, 1976). This change in the role of the teacher required administration to develop new resourceful staffing and training practices to assure that the type of teacher needed was hired (Knowles, 1976).

The literature revealed that the number of nontraditional students is going to continue to increase (Altbach et al., 2005; Kasworm, 2012; Merriam et al., 2007; National Center for Education Statistics [NCES], n.b.b; USBC, 2010). The competition for adult learners, therefore, is also going to continue to increase for colleges and universities (Tannehill, 2009). As a result, institutions that "continue to focus on the traditional students," as opposed to giving equitable consideration to nontraditional students, "may find themselves trying to figure out how to keep their doors open as the number of traditional students continues to decline" (p. 129) asserted Tannehill.

\section{Research on Andragogy}

Insufficient empirical research has been conducted on andragogy despite its 40-year history of being considered the principal model of adult learning (Laird, Naquin, \& Holton 2003; Merriam et al., 2007; Noe, 2010). The majority of the research completed is actually in the practice of andragogy. Knowles' book Andragogy in Action: Applying Modern Principles of Adult Learning (1984), for example, provided examples of application of the andragogical model in business and industry. In his book Knowles assembled studies based on the assumptions of andragogy he had received from professionals in business and industry. These studies were completed in the workplace. Knowles included 36 of over 100 studies and categorized them according to institutional type. According to Knowles, the most beneficial theme of his book was "the power of the notion that people learn best when treated as human beings" (p. xvi).

Henschke (2011a) claimed that there are 330 published documents on andragogy by various authors. He recognized six distinct themes in this research. Those distinct themes include the evolution of the term andragogy; historical antecedents shaping the concept of andragogy; comparisons of the American and European understandings of andragogy; promoting and maintaining the American and worldwide views of andragogy; practical applications of andragogy; and theory, research, and definition of andragogy.

Research on adult education has been descriptive for the most part. Furthermore, this research has been in the practice of adult learning in business and industry rather than on teaching adults. A number of publications have focused on learning experiences aimed at sharing this information with others in the field. This research, sadly, has not added to the scholarly body of knowledge. There has also been a shift in research from broad overviews and application of findings to an understanding of observable facts. The tendency has been to translate practice into research rather than translating research into practice. Research on adult education, regrettably, has been fragmented and inconsistent. What research there is has not been translated into practice in higher education. Alas, educators are not commonly trained in adult education (Brookfield, 2006; Rose, 2000).

\section{A Need for Andragogy}

A different method of instruction is required for educating adult learners. The need for a distinctive method is due to the more complex lives of today's adults. The usual pedagogical methods are not adequate to meet the needs of these nontraditional students and their complicated lives. For example, the education of the youth is a teacher-centered 
approach calling for a transfer of information and requiring the student to memorize. On the other hand, andragogical methods are required replacing teacher-centeredness, the transfer of information, and student memorization with problem-solving skills (Loeng, 2013).

In the Interdisciplinary Studies Program at the University of Southern Mississippi, students took the initiative to learn by designing their own degree plans within broad boundaries established by the university. Students expressed enjoyment of education as a result of having control over their learning. They also expressed the enjoyment of having the benefit of a renewal of the "love of learning" (Harper \& Ross, 2011, p. 166). Furthermore, the faculty benefited from the experience as well. They were able to examine their own scholarship, values, and practice. The faculty believed, according to the researchers, that efforts to encourage adult learners to become autonomous learners were both beneficial and rewarding.

Law students from the Third and Fourth Districts of Idaho claimed that the andragogical principles espoused by Knowles were the most helpful in their preparation for practicing law. Students claimed they learned the most in classes that employed the assumptions of andragogy. Students became more self-directed in these classes. They were more receptive to the traditional customs of practicing law when educators applied course content to experiences and stated that the classes "came alive" (Taylor, 2010, p. 185). Overall, students were more willing to go through the learning process when they were informed about what they would learn and the reasons for learning. When experienced attorneys discussed practical experiences on the job, moreover, students tended to learn more. The Chinese proverb holds true, "a single conversation with a wise man is better than ten years of study" (p. 53) asserted Taylor and Kroth (2009).

Management education also fits well with the assumptions of andragogy. In fact, management education in higher education could be called andragogy. This is because the instructional strategies utilized in management courses are often effective for adult students maintained Forrest and Peterson (2006). As a result, numerous management educators unknowingly teach from an andragogical perspective. The American Management Association's master's degree program in management was structured around andragogy and competency-based education (Knowles, 1984).

Andragogy allows management educators to employ traditional teaching methods in unique ways. If the educator asks students what they need to know and incorporate the responses into the lectures, for example, lectures can be effective methods of instruction. Further, students will be more interested in the lectures on creating a mission statement when they understand the importance of mission statements to organizations. When lectures are based on students' desires to learn the information, the lecture method is effective. Unfortunately, the pedagogical method of teaching remains prevalent in the typical university classroom (Forrest \& Peterson, 2006).

Tannehill (2009) surveyed college and university administrators on the use of andragogy in the classroom. According to the researcher, staff members could benefit from formal education on andragogy and college and university administrators should be well educated on andragogy. Higher education is encouraged to consider including courses on andragogy as part of the master's and doctoral curricula for future administrators. Students, 25 years old and older are the fastest growing segment of the student body in higher education. Unfortunately, most administrators know little about educating these students. Colleges and universities that provide the "whole package" (p. 128) to adult learners will be the ultimate 
survivors claimed Tannehill.

Educators are encouraged to invest time and effort in strengthening their knowledge of andragogy (Chan, 2010; Kiener, 2010; Minter, 2011; Yow, 2010). Educators are also encouraged to consider adult learning principles when designing curricula that focus on the needs of adult learners (Knight, 1999; Yow, 2010). Educators, administrators, and policy makers are advised to consider implementing effective efforts to ensure that the needs of adult learners are met. Yow (2010) recommended that a good starting point is for educators to consider Knowles' six assumptions in daily teaching practices. The most effective learning will ultimately transpire when adult learners can link skills with application suggested Yow.

Taylor and Kroth (2009) designed a teaching methodology instrument and tested it in a law school classroom using the Socratic method of instruction. They believed that the Socratic method of instruction encourages law students to "think like a lawyer" (p. 44). If this instrument could predict whether pedagogical or andragogical methods were used, claimed the researchers, it would encourage educators to consider their own teaching styles. This would advance the integration of the six andragogical assumptions espoused by Knowles in higher education. This integration into higher education teaching methodologies could ultimately result in better educational experiences for adults claimed Taylor and Kroth.

Martell (2011) found similar results when students were taught bible lessons following some of the principles of andragogy. Martell compared the effectiveness of a lecture-based, pedagogical teaching philosophy to a discussion-based, andragogical teaching philosophy in adult bible fellowships (ABFs) at The Chapel in Akron, Ohio. Findings suggested that students learned more with andragogical principles, enjoyed the andragogical teaching methods, believed the lessons were more memorable, and practiced the new knowledge in their everyday lives. The students were more confident about their learning maintained Martell.

The andragogical model has also had an impact on the teaching philosophy of educators internationally asserted Chan (2010). Because of this international impact, educators and educational institutions globally are encouraged to make opportunities available to all learners to be involved in learner-centered educational experiences. Educators are also encouraged to consider adopting and applying andragogical methods that create a more engaging learning environment to prepare students to compete in the 21st century workplace. Adult learners need a more active role in the planning and learning processes, they need to understand the learning, and they need to apply the learning in their everyday lives.

Kiener (2010) recommended that faculty frequently examine their roles as educators. This examination includes assessing their role of teaching, their own teaching philosophies, how students learn, and their use of the assumptions of andragogy in the classroom. Regardless of how many classes they teach per semester, members of the faculty have these ethical responsibilities to the students they teach avowed Kiener.

\section{Learning How to Learn}

According to Hadley (1975), the purpose of learning is to allow adult learners to execute personal growth according to what that growth specifically means to them. Hence, learners are learning how to learn. This practice, in turn, enables learners to form their own understanding of their realities. Learners grow to know themselves, to know their talents, and to know their desires. This self-knowledge is of great importance to adult learners asserted 
Knowles (1984). Sadly, educators have historically viewed themselves as more andragogical than their students have viewed them averred Hadley.

Andragogy requires learners to participate in all aspects of learning, from directing the learning process to incorporating past experiences. Andragogy advances a mutual relationship between the learner and educator in managing the learning process. According to Hadley (1975), andragogy furthers a two-way, equally dependent interaction of mutuality and reciprocity aimed at joint development. In order for learning to be effective, the focus of learning must be on the adult learner gaining self-confidence. This self-confidence will subsequently motivate the learner to continue learning and build on past knowledge and experiences.

Institutions establish the overall criteria for learning. The educator is in charge of the design of the learning process and uses his or her influence to assure the learner accomplishes the objectives through mutuality and reciprocity. However, the learner's personal objective is most important. The ongoing challenge for the educator is to encourage adult learners to continue to select more complex objectives to test and enhance learning. Hence, the relationship between educator and learner is one of expressing and sharing (Hadley, 1975).

\section{Teaching Andragogically}

Beder and Darkenwald (1982) were interested in ascertaining whether instructors taught adult learners differently than they taught pre-adult learners. Data were collected from 173 public school and college teachers with a median age 41.8 years. These instructors taught both adults and pre-adults. Teachers indicated that they taught andragogically to the adult learners by accentuating responsive, learner-centered instruction that de-accentuates power and rules. This andragogical practice in the classroom was confirmed in the findings of the study results. The adult learners were seen as more motivated, pragmatic, self-directed, and task-oriented than were pre-adult learners indicated the researchers.

Gorham (1985) analyzed reported and observed teaching practices of 115 university, community college, and public school instructors who taught adult and pre-adult learners. Even though the instructors reported teaching adult learners and pre-adult learners differently, results yielded little evidence of student-centered approaches. Comparative analysis was used to study aspects that emerged and affected interactions in adult education classrooms. According to the researcher, the interaction investigation was supported by offering impartial accounts of teaching behaviors, which might be developed for future training of adults.

According to Clerk (2012), educators are encouraged to understand that adult learners enroll in education with different needs than pre-adult learners. Furthermore, adult learners have pre-formed biases and ideas about education. These pre-formed biases and ideas developed through life experiences could unfortunately represent barriers to education (Clerk; Kasworm, 2012; Pew, 2007). It is important, therefore, that educators communicate to adult learners the impact, method, and implementation of learning. It is also important that educators understand that adult learners have different learning styles and preferences and learners are ready to move on to the next learning experience once learning is internalized claimed Clerk.

Hughes and Berry (2011) noted that instructors are encouraged to understand that adult learners have been recognized as being intellectual and technological. Therefore, adult learners should be provided opportunities to be involved in making decisions for their own 
learning methods. They should also be provided with opportunities for information collection rather than being hand-fed information. If this collaboration is initiated early in the process, adult students appreciate having control of their own learning and will demonstrate the value of education. Educators are also encouraged to consider collaborating with students when developing courses maintained the researchers.

Adult learners tend to behave dependently when they are in a more structured educational setting claimed Knowles (1984). This dependence may be because learners do not know how to learn, they only know how to be taught. However, the main purpose of education is to acquire the ability to inquire and to go on acquiring new knowledge throughout life. Therefore, society must not think of learning as only something that takes place in an institution. Education is something that is a part of life. Education is a prerequisite in this evolving world (Knowles, 1976).

Clemente (2010) discovered that Knowles' model of andragogy is compatible with experiences of adult students in multi-generational community college classrooms in a number of ways. Clemente found that the self-concept of adult learners moves over time from that of dependency to self-directing. Furthermore, over time adult learners overcame anxiety. They became more at ease with being students and interacting with their colleagues. Adult students also took responsibility for managing their coursework. Into the bargain, previous experiences of adult learners provide rich resources for discussions and learning in the classroom suggested Clemente.

In a study conducted on web-based distance education (WBDE) for adult learners, Zhang (2009) claimed that most distance education students are adult learners. The researcher also claimed that learning is more meaningful if both the educator and the learner shared the responsibility for the design of learning goals and objectives, interacted with other members of the class, promoted reflection on experiences, related new examples that made sense to the learner, maintained self-directed learning, and evaluated learning. This shared responsibility is both an opportunity and challenge for WBDE according to Zhang.

In consideration of computer learning, Knight (1999) found that learning and confidence increase when adult learners are provided opportunities for hands-on computer learning. Allowing students to maintain control of the mouse and the computer keyboard also increased learning outcomes. Therefore, it is important that computer programs and manuals be easy to work with and easy to understand. This ease provides opportunities for self-paced independent learning. Learning is often impacted by the education level and occupation of adult learners maintained Knight. Instructors are encouraged, as a result, to consider the needs of the student when assessing the classes and designing the curriculum.

Research has suggested that Knowles' assumptions of andragogy are compatible with blended learning tenets (Korr, Derwin, Greene, and Sokoloff, 2012). Blended courses are defined as "those that deliver course material in face-to-face and online formats and that allow students to collaborate with instructors and peers in these different settings" (Caruth \& Caruth, 2012, para. 5). Korr et al. (2012) claimed that blended learning and andragogy correspond according to the following: learners compare information to past experiences to establish new information, learners consider busy work as offensive, learners separate new learning from their everyday lives, learners anticipate individualized feedback from educators as opposed to just receiving a grade, and learners are inspired by relevant problem-solving activities. Students have more time to compare new information and past experiences than they do in 
traditional face-to-face classroom settings due to the flexibility of time constraints of blended courses. Interactive online assignments tend to reduce the feelings of being assigned busy work activities. Additionally, collaboration with peers from locations outside the classroom minimizes the sense students often feel of separation in blended classes. It is important that continuous feedback is provided students through electronic means asserted Korr et al. (2012).

Instructors affect learning outcomes (Knight, 1999). Therefore, providing a supportive environment is critical for learning success of adult learners. An environment that lacks support or offers negative responses impedes learning. On the other hand, positive responses encourage learning. Granting opportunities to ask questions and make mistakes free from criticism and time-constraints encourages self-directed learning. Offering adult students the time to work through problems also results in learning. Hence, instructors can enhance learning by being available for questions and providing answers free of disapproval avowed Knight.

Educators of adult learners are encouraged to support organizational learning in their respective institutions. They are also encouraged to initiate communication with colleagues on teaching and learning models by discussing pedagogical and andragogical tenets and sharing teaching experiences. Unfortunately, instructors frequently use a mixture of learning theory and practice and they may not even be conscious of what theory or model of learning they implement in the classroom. Rather, their instructional efforts are based on their individual internal concept of what is appropriate without knowing whether learning theory or research supports their instructional methods practiced in the classroom suggested Minter (2011).

Adult educators are encouraged to work with adult learners to offer choices and opportunities. Educators are advised to remember that the majority of students encounter at least one educational barrier in their lifetimes. As a result, educators are also advised to consider all potential complexities of adult learners (Finn, 2011; Ritt, 2008). Educators are forewarned to bear in mind that many adult learners are more likely to leave educational institutions without earning a college degree due to these additional barriers (Kasworm, 2012; Tannehill, 2009).

Individuals tend to form impressions of new experiences that may last a lifetime. These impressions can include any form of adult learning or education indicated Finn (2011). The main barrier for adult learners returning to school is often the coordination of responsibilities (work, family, school, care receivers, volunteer organizations, community, etc.). However, adults who return to school are internally motivated to succeed maintained the researcher. They understand the need to comply with employer requirements or improve their job skills. They often want opportunities to make positive impacts (Anderson, 2007). Therefore, considering the importance of providing an inviting environment will help offset the challenges of educational barriers. Inviting learning environments encourage adults to continue learning opportunities. Inviting environments help to overcome barriers to further education (Finn, 2011; Kasworm, 2012).

Nontraditional, adult learners frequently have needs that traditional students do not have; consequently, they require different student services. University orientation programs commonly are not designed with older adult students in mind maintained Tatum (2010). These nontraditional students generally have more complex lives than do the traditional students. For example, older students are often responsible to and for families, employers, care receivers, school, community, volunteer organizations, etc. (Kasworm, 2012; Tatum). 
Adult learners also have experience with families, employment, and the military which can be valuable to younger students when shared. What is more, these adult students can be a rich resource for traditional younger students. Administrators should take advantage of the knowledge and experiences of nontraditional students in the classrooms. Mentoring relationships should be established to benefit traditional and nontraditional older students mutually. Adult students can and should be encouraged to act as mentors or role models for traditional younger students claimed Tatum.

University administrators are advised to design programs and services with nontraditional older students in mind recommended Tatum (2010). Orientation programs, for example, should be designed at convenient times and locations for older students. Adult learners should also be assigned advisors who are familiar with the needs of older students. Consideration of the time constraints of the older students is ultimately important. This growing diverse student body has had an impact on the services and programs once provided exclusively to traditional students. Therefore, these services and programs should consider the needs of diverse students.

Cretchley and Castle (2001) suggested that andragogy has had an influence on the values and teaching philosophies of adult educators in a number of countries. For example, South Africa applied the andragogical method to adult higher education thereby offering a measure of empowerment for adult learners. According to the researchers, the andragogical method offered an antidote to the domination of education in an undemocratic society. In other words, adult learners need to direct the learning process because society does not have the right to either socialize or re-socialize society according to Cretchley and Castle.

In a study that compared higher education in Germany, the United Kingdom, and Japan (Yoshimoto, Inenaga, and Yamada, 2007), andragogy was considered learner-focused and was aligned with the concept of teaching when compared to pedagogy, which is teacherfocused and in-line with the idea of learning support. Often the andragogical method of teaching is compared to "off-campus open learning" (p. 80). Historically, a traditional university education was viewed as being for young and elite students. However, universal access meant the inclusion of nontraditional students in the study body.

Andragogy should be empirically researched in higher education as it relates to evaluations of educational outcomes averred Yoshimoto et al. (2007). This evaluation is gathering interest in Japan where universities need to offer opportunities for older students. In Germany, pedagogies should be developed because of university reforms maintained the researchers. In the United Kingdom, adult learners are enrolling in classes on a part-time basis in new (nontraditional) universities, as opposed to young full-time students who enroll in traditional universities. The application of higher education in working life may be different in these two universities. Germany, the United Kingdom, and Japan implemented a two-tiered approach that considered that andragogical methods could also be more suitable for younger students on occasion than just for adult learners, suggested Yoshimoto et al.

\section{A Need for Further Research}

Andragogy is not without its critics. Hartree (1984) critiqued Knowles' assumptions of andragogy based on a lack of clarity and a general ambiguity. Hartree stated that the relationship between adult and child learners is unclear. Knowles assumptions are vague maintained the researcher. She also claimed that andragogy is based on man's "existence" (p. 
208), which explains the confusion over whether andragogy is about adult learning or about teaching adults.

Knowles (1976) recognized the need for further research on andragogy. He suggested that an attitude of "mutual inquiry" (p. 15) was needed to develop further the field of adult education and this attitude of mutual inquiry is "pioneering" (p. 16). This pursuit of research on andragogy requires a joint effort of patience and collaboration. Individuals who require "pat answers, neat categories, and proved theories will be uncomfortable in the climate" (p. 16) of andragogy and adult education in its current state maintained Knowles. Clearly, andragogy requires honest empirical research before some of the issues presented in Hartree's critique can be resolved.

Assessment of adult learners has posed an additional challenge for educators who attempt to practice andragogy by becoming more of a "guide on the side" rather than a "sage on the stage" in the classroom. This role of facilitator is hindered when it comes to grading and evaluating adult students. Final evaluations are often determined by the educator's criteria claimed Beaman (1998). These grading criteria include multiple choice exams, short answer exams, and projects graded by the instructor. Grading undermines previous efforts for student empowerment (Beaman, 1998).

Adult learners expect and need assessments for feedback, motivation, and evaluation purposes. Evaluations and grading are complex and an important part of the communication process between educators and learners. Effective assessments can lead to learning experiences that are more meaningful maintained Beaman (1998). Alternative options to traditional evaluation approaches include peer evaluations, self-assessments, praiseworthy grading (pointing out successes rather than failures), and checklists for quality (measurements of the quality of an idea). Praiseworthy grading and checklists for quality provide instructor input in a more facilitative manner than with traditional grading approaches. It is important to consider who does the grading and how the grading is accomplished. According to the literature, adult learners need to be involved in these assessments; therefore, traditional grading methods need to change (Beaman). Regardless, educators should consider selfdiagnosis with input from the educator and peers in the evaluation process asserted Hadley (1975).

Knowles et al. (2011) suggested that the main reason strong empirical research on andragogy does not exist is that there has not been a psychometrically valid instrument available to measure the constructs of andragogy (Holton, Wilson, and Bates, 2009). While a number of attempts to develop such an instrument do exist, most attempts have not succeeded for an assortment of reasons. Knowles developed one such instrument, for example, that had not been validated.

The development of the Andragogical Practices Inventory (API) by Suanmali (1981) that successfully measured andragogical assumptions is very significant. The API design and accessibility for empirical research in the future is an important development for the discipline of andragogy and adult education. Holton et al. (2009) proposed that further research involving instruments to test the principles of andragogy is needed to ascertain whether combining the modification and orientation to learning assumptions is justified and presents opportunities for future research. Henschke developed and validated the Instructor Perspective Inventory (IPI). Of note, the IPI has been validated in four other studies. The IPI was modified from a 4-point to a 5-point Likert Scale, which resulted in the Modified 
Instructor Perspective Inventory (MIPI). The MIPI has been used as a research instrument in a number of doctoral dissertations and continues to be used ( $\mathrm{J}$. Henschke, personal communication, May 31, 2012).

In summary, the purposes and methods of adult learning will continue to be debated and, as this occurs, advances are likely to take place in the future research and practice in andragogy (Knowles et al., 2011). A review of the literature revealed the following major points:

- There has been a substantial increase of adult students enrolled in college and university classes (Altbach et al., 2005; Caruth, 2013; Finn, 2011; Harper \& Ross, 2011; Knowles, 1984; Marschall \& Davis, 2012; Merriam et al., 2007; NCES, n.d.a).

- Andragogy is not being used in the higher education classrooms (Beder \& Darkenwald, 1982; Brookfield, 2006; Caruth, 2013; Gorham, 1985; Hadley, 1975; Harper \& Ross, 2011; J. Henschke, February 2, 2012; Knowles, 1968; Knowles, 1976; Pew, 2007; Rose, 2000).

- Adults should be taught andragogically (Beaman, 1998; Caruth, 2013; Chan, 2010; Clemente, 2010; Clerk, 2012; Forrest \& Peterson, 2006; Hadley, 1975; Hughes \& Berry, 2011; Kiener, 2010; Knight, 1999; Knowles et al., 2011; Loeng, 2013; Martell, 2011; Tatum, 2010; Taylor, 2010; Yow, 2010; Zhang, 2009).

- Colleges and universities need to prepare to teach adult students andragogically (Anderson, 2007; Beaman, 1998; Caruth, 2013; Chan, 2010; Clerk, 2012; Finn, 2011; Hadley, 1975; Hughes \& Berry, 2011; Minter, 2011: Kiener, 2010; Knight, 1999; Ritt, 2008; Tannehill, 2009; Tatum, 2010; Taylor \& Kroth, 2009; Yow, 2010).

- Higher education is not doing the job needed to teach adult learners effectively (Brookfield, 2006; Caruth, 2013; Harper \& Ross, 2011; Knowles, 1968; Rose, 2000).

\section{Implications}

The availability of instruments to measure the constructs of andragogy in empirical research will strengthen the foundation of andragogy. Predictive research can be completed to study the effect of andragogical practices on learning and student satisfaction outcomes. In the past, andragogy has experienced a lack of empirical tests. However, with validated and reliable instruments available to measure the constructs of andragogy, clearer validation of andragogy in higher education is promising (Holton et al., 2009).

\section{Recommendations}

It is recommended that further research on andragogy be completed to measure the constructs of andragogy. Further research is needed involving instruments to test the principles of andragogy to ascertain whether combining the modification and orientation to learning assumptions is justified and presents opportunities for future research.

\section{References}

Altbach, P., Berdahl, R., \& Gumport, P. (2005). American higher education in the twenty-first century (2nd ed.). Baltimore, MD: Johns Hopkins University.

Anderson, J. M. (2007). A conceptual framework of a study in preferred learning styles: Pedagogy or andragogy (Unpublished doctoral dissertation). Spalding University, Louisville, Kentucky. 
Beaman, R. (1998). The unquiet...even loud, andragogy! Alternative assessments for adult learners. Innovative Higher Education, 23, 47-59. doi:10.1023/A:1022920513341

Beder, H. W., \& Darkenwald, G. G. (1982). Differences between teaching adults and preadults: Some propositions and findings. Adult Education, 32(3), 142-155. doi: $10.1177 / 074171368203200303$

Brookfield, S. D. (2006). The skillful teacher: On technique, trust, and responsiveness in the classroom (2nd ed.). San Francisco, CA: Jossey-Bass.

Caruth, G. (2013). Andragogy in higher education: Identifying 2010 adult learners in baccalaureate degree-granting institutions. (Unpublished doctoral dissertation). Texas A \& M University-Commerce, Commerce, TX.

Caruth, G. D. \& Caruth, D. L. (2012). Significant trends in online education. Journal of Online Education. http://www.nyu.edu/classes/keefer/waoe/waoej.html.

Chan, S. (2010). Applications of andragogy in multi-disciplined teaching and learning. Journal of Adult Education, 39(2), 25-35.

Clemente, K. A. (2010). Experiences of adult students in multi-generational community college classrooms (Unpublished doctoral dissertation). Pennsylvania State University, University Park, PA.

Clerk, K. (2010). Student perception and success: How adult learners at a two-year technical institution perceive instruction and how their perceptions contribute to their overall academic success (Unpublished doctoral dissertation). Oakland University, Rochester, MI.

Cretchley, G., \& Castle, J. (2001). OBE, RPL, and adult education: Good bedfellows in higher education in South Africa? International Journal of Lifelong Education, 20(6), 487-501.

Finn, D. (2011). Principles of adult learning: An ESL context. Journal of Adult Education, 40, 34-39.

Forrest, S. P., \& Peterson, T. O. (2006). It's called andragogy. Academy of Management Learning \& Education, 5, 113-122.

Gorham, J. (1985). Differences between teaching adults and pre-adults: A closer look. Adult Education Quarterly, 35(4), 194-209. doi:10.1177/0001848185035004002

Hadley, H. N. (1975). Development of an instrument to determine adult educator's orientation as andragogical and pedagogical (Unpublished doctoral dissertation). Boston University School of Education, Boston, MA.

Harper, L., \& Ross, J. (2011). An application of Knowles' theories of adult education to an undergraduate interdisciplinary studies degree program. The Journal of Continuing Higher Education, 59, 161-166. doi:10.1080/07377363.2011.614887

Hartree, A. (1984). Malcolm Knowles' theory of andragogy: A critique. International Journal of Lifelong Education, 3(3), 203-210. doi:10.1080/0260137840030304

Henschke, J. A. (2011a). Considerations regarding the future of andragogy. Adult Learning, Futures Column, 22, 34-37. doi:10.1177/104515951102200109

Holton, E. F., Wilson, L. S., \& Bates, R. A. (2009). Toward development of a generalized instrument to measure andragogy. Human Resource Development Quarterly, 20(2), 169-193. doi:10.1002/hrdq.20014

Hughes, B. J., \& Berry, D. C. (2011). Self-directed learning and the millennial athletic training student. Athletic Training Education Journal, 6, 46-50.

Kasworm, C. E. (2012). US adult higher education: One context of lifelong learning. International Journal of Continuing Education and Lifelong Learning, 5(1), 1-19.

Kiener, M. (2010). Examining college teaching: A coaching perspective. Rehabilitation Education, 24(1/2), 69-74. 
Knight, K. J. (1999). Older adults and technology: A critical incident inquiry into learning experiences (Unpublished doctoral dissertation). Texas A\&M University-Commerce, Commerce, TX.

Knowles, M. S. (1968). Andragogy, not pedagogy. Adult Leadership, 16(10), 350-352, 386.

Knowles, M. S. (1976). The modern practice of adult education: Andragogy versus pedagogy. New York, NY: Association Press.

Knowles, M. S. (1984). Andragogy in action: Applying modern principles of adult learning. San Francisco, CA: Jossey-Bass.

Knowles, M. S., Holton, E. F., \& Swanson, R. A. (2011). The adult learner: The definitive classic in adult education and human resource development (7th ed.). Burlington, MA: Butterworth-Heinemann.

Korr, J., Derwin, E. B., Greene, K., \& Sokoloff, W. (2012). Transitioning an adult-serving university to a blended learning model. Journal of Continuing Higher Education, 60, 2-11. doi:10.1080/07377363.2012.649123

Laird, D., Naquin, S. S., \& Holton, E. F. (2003). Approaches to training and development (3rd. ed.). New York, NY: Basic Books.

Loeng, S. (2013). Eugen Rosenstock-Huessy - an andragogical pioneer. Studies in Continuing Education, 35(2), 241-253. doi: 10.1080/0158037X.2012.749850

Levitt, L. (1979). Critique: Andragogy revisited II. Adult Education Quarterly, 30, 52-57. doi:10.1177/074171367903000104

Marschall, S., \& Davis, C. (2012) A conceptual framework for teaching critical reading to adult college students. Adult Learning, 23(2), 63-68. doi:10.1177/1045159512444265

Martell, J. (2011). Evaluating the effectiveness of andragogical teaching in adult bible fellowships at The Chapel, Akron, Ohio (Unpublished doctoral dissertation). The Southern Baptist Theological Seminary, Louisville, KY.

Merriam, S. B., Caffarella, R. S., \& Baumgartner, L. M. (2007). Learning in adulthood: A comprehensive guide (3rd ed.). San Francisco, CA: Jossey-Bass.

Minter, R. L. (2011). The learning theory jungle. Journal of College Teaching \& Learning, $8(6), 7-15$.

National Center for Education Statistics, (n.d.a). Digest of education statistics, 2010, Chapter 3: Postsecondary education enrollment, table 199. Washington, DC: Author.

National Center for Education Statistics, (n.d.b). Digest of education statistics, 2010, Projections of education statistics: Section 5. Enrollment in postsecondary degreegranting institutions: Enrollment by selected characteristics and control of institution, table 21. Washington, DC: Author.

Noe, R. A. (2010). Employee training \& development (5th ed.). New York, NY: McGrawHill.

Pew, S. (2007). Andragogy and pedagogy as foundational theory for student motivation in higher education. Insight: A collection of faculty scholarship, 2, 14-25.

Ritt, E. (2008). Redefining tradition: Adult learners and higher education. Adult Learning, 19(1/2), 12-16. doi:10.1177/104515950801900103

Rose, A. D. (2000). What is the state of adult education research today? Adult Learning, 11(4), 28-29. doi:10.1177/104515959901100410

Rudolph, F. (1990). The American college and university: A history (2nd ed.). Athens, GA: University of Georgia Press.

Suanmali, C. (1981). The core concepts of andragogy. (Unpublished doctoral dissertation) Ann Arbor: Dissertation Abstracts International. (UMI No. 8207343).

Tannehill, D. B. (2009). Andragogy: How do post-secondary institutions educate and service adult learners? (Unpublished doctoral dissertation). University of Pittsburgh, Pittsburgh, PA. 
Tatum, C.G. (2010). An explanatory mixed methods inquiry into the academic experience of nontraditional community college students (Unpublished doctoral dissertation). Texas A\&M University-Commerce, Commerce, TX.

Taylor, B. F. (2010). Raising the bar: A qualitative study of adult learning theory and its effectiveness of law school education in preparing new graduates to begin the practice of law (Unpublished doctoral dissertation).University of Iowa, Iowa City, IA.

Taylor, B. F., \& Kroth, M. (2009). A single conversation with a wise man is better than ten years of study: A model for testing methodologies for pedagogy or andragogy [Electronic version]. Journal of the Scholarship of Teaching and Learning, 9(2), 4256.

Thelin, J. R. (2004). A history of American higher education. Baltimore, MD: Johns Hopkins University Press.

U.S. Bureau of the Census. (2010). The older population: 2010. Retrieved from http://2010.census.gov

Yoshimoto, K., Inenaga, Y., \& Yamada, H. (2007). Pedagogy and andragogy in higher education - A comparison between Germany, the UK and Japan. European Journal of Education, 42, 75-98.

Yow, A. (2010). Employers' perceptions of basic technology skills needed for workplace preparation in adult basic education (Unpublished doctoral dissertation). Walden University School of Education, Minneapolis, MN.

Zhang, J. (2009). Exploring education major focused adult learners' perspectives and practices of Web-based distance education in sixteen universities (Unpublished doctoral dissertation). New Mexico State University, Las Cruces, NM. 